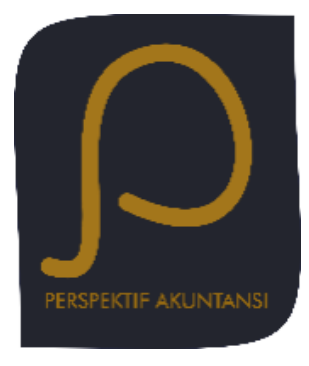

Perspektif Akuntansi

Volume 1 Nomor 1 (Oktober 2018), hal. 53-70

ISSN: 2623-0194(Print), 2623-0186(Online) Copyright $(\mathrm{C}$ The Authors(s). All Rights Reserved

Fakultas Ekonomika dan Bisnis, Universitas Kristen Satya Wacana

DOI: https://doi.org/10.24246/persi.v1i1.p53-70 http://ejournal.uksw.edu/persi

\title{
Tanggung Jawab Sosial Perusahaan dilihat dari Sudut Pandang Teori Akuntansi Positif
}

\author{
Yunita Putri Utami \\ Universitas Kristen Satya Wacana \\ Hans Hananto Andreas ${ }^{1}$ \\ Universitas Kristen Satya Wacana
}

Received Abstract. The purpose of this study is to determine the effect of bonus 18/03/2018 plans, debt ratios, and political costs on the disclosure of corporate social responsibility listed on the Indonesia Stock Exchange in 2014-2016. Bonus

Accepted plan is measured by return on assets (ROA), debt ratio is measured by debt 28/06/2018 to equity ratio (DER), political cost is measured by total company asset, while CSR disclosure is measured using GRI G4 standard. The sample was taken by purposive sampling method, with total sample of 288 companies. The bonus plans and political costs have a positive effect on corporate social responsibility disclosure, while the debt ratio has no effect.

Keywords: Bonus plan, debt ratio, political cost, CSR.

\begin{abstract}
Abstrak. Tujuan penelitian ini adalah untuk mengetahui pengaruh rencana bonus, rasio hutang, dan biaya politik terhadap tanggung jawab sosial perusahaan manufaktur yang terdaftar di Bursa Efek Indonesia pada tahun 2014-2016. Rencana bonus diukur dengan return on assets (ROA), rasio hutang diukur menggunakan debt to equity ratio (DER), biaya politik diukur dengan total aset perusahaan, sedangkan CSR diukur menggunakan standar GRI G4. Sampel diambil dengan metode purposive sampling, dengan total sampel sebanyak 288 perusahaan. Rencana bonus dan biaya politik berpengaruh positif terhadap tanggung jawab sosial perusahaan, sedangkan rasio hutang tidak berpengaruh terhadap tanggung jawab sosial perusahaan.
\end{abstract}

Kata kunci: Rencana bonus, rasio hutang, biaya politik, CSR.

1 hananto.andreas@staff.uksw.edu 


\section{Pendahuluan}

Kemajuan teknologi saat ini mendorong pertumbuhan industri menjadi semakin pesat, khususnya industri di bidang pengolahan sumber daya alam. Akibatnya eksploitasi alam semakin meningkat, bukan hanya disebabkan oleh pabrik-pabrik baru, namun juga oleh perusahaan-perusahaan yang telah lama berdiri. Hal ini mendorong kerusakan lingkungan yang marak terjadi akhirakhir ini. Tidak dipungkiri bahwa di Indonesia banyak terjadi kerusakan lingkungan sebagai akibat dari kegiatan operasional perusahaan-perusahaan besar. Setyorini \& Ishak (2012) menyatakan bahwa terdapat kasus yang terjadi di Indonesia sehingga menyebabkan publik dan masyarakat membuka mata tedap pentingnya tanggung jawab sosial perusahaan diantaranya yaitu kasus PT Lapindo Brantas di Jawa Timur yang menyebabkan semburan lumpur sehingga menenggelamkan delapan desa dan 13.000 warga dievakuasi, dan pencemaran air minum yang disebabkan oleh polusi arsen di Papua Barat oleh PT Freeport. Kasus-kasus ini telah membuka mata masyarakat umum, perusahaan serta regulator mengenai pentingnya tanggung jawab sosial perusahaan.

Tanggung jawab sosial perusahaan atau Corporate Social Responsibility (CSR) muncul sebagai respon masyarakat terhadap industrialisasi perusahaan besar yang menimbulkan berbagai permasalahan ekologi, HAM, dan permasalahan sosial lainnya yang perlu untuk segera ditangani (Khodir, 2012). Untuk dapat berkembang, perusahaan seharusnya tidak hanya memperhatikan keuntungan saja namun berorientasi pada prinsip Triple Bottom Line yaitu keuntungan (profit), kesejahteraan masyarakat (people), serta ikut berperan aktif melestarikan lingkungan (planet) (Elkington, 1999). Dalam rangka mencapai tujuan keberlanjutan bagi masa depan perusahaan, maka sebaiknya perusahaan mulai menaruh perhatian pada tanggung jawab sosialnya. Malhotra (2013) menyatakan terdapat hubungan yang kuat antara CSR dan strategi. SWA magazine pada tahun 2005, menyatakan bahwa CSR adalah istilah yang paling populer digunakan sebagai strategi sebagaimana diindikasikan oleh 31\% responden (Setyorini \& Ishak, 2012).

Menanggapi berbagai isu yang muncul sebagai akibat dari eksploitasi sumber daya alam oleh perusahaan, pemerintah melalui peraturan Undang-Undang Nomor 40 Tahun 2007 tentang Perseroan Terbatas pasal 74 ayat (1) mewajibkan perseroan yang bergerak di bidang sumber daya alam untuk melaksanakan tanggung jawab sosial dan lingkungan. Pelaksanaan CSR di Indonesia sangat tergantung pada pimpinan puncak korporasi (Badjuri, 2011). Pimpinan perusahan berperan penting dalam pelaksanaan CSR. Di sisi lain pimpinan perusahaan, dalam hal ini manajer, memiliki wewenang untuk memilih kebijakan akuntansi bagi perusahaan. Manajer dapat meningkatkan 
laba dengan menghemat biaya kegiatan sosial, namun manajer juga dapat menurunkan laba untuk dapat menghindari tuntutan perolehan laba yang lebih baik dari para investor sekaligus meningkatkan citra perusahaan, dengan mengalokasikan laba pada kegiatan sosial (Agustina, Sulia, \& Rice, 2017).

Motivasi perusahaan di dalam melakukan pengungkapan tanggung jawab sosial perusahaan dapat dijelaskan melalui teori akuntansi positif. Teori akuntansi positif (positive accounting theory/PAT) merupakan sebuah teori yang timbul akibat ketidakpuasan terhadap teori akuntansi normatif. PAT bertujuan untuk menjelaskan bagaimana informasi keuangan disajikan kepada para pengguna informasi akuntansi atau dengan kata lain mengapa praktik akuntansi mencapai bentuk seperti keadaannya sekarang (Januarti, 2004). Dalam konteks tanggung jawab sosial perusahaan, teori ini berguna untuk mengidentifikasi bagaimana sebuah kebijakan akuntansi berpengaruh terhadap kegiatan sosialnya. Berdasarkan PAT, sebuah perusahaan terdiri dari sekumpulan kontrak diantara para pelaku ekonomi yang bersikap oportunistik (Watts \& Zimmerman, 1990). Menurut Watts \& Zimmerman (1990) teori akuntansi positif dalam bentuk oportunistik sering diintepretasikan melalui tiga hipotesis yaitu bonus plan hypothesis, debt hypothesis, serta political cost hypothesis.

Penelitian mengenai CSR dari sudut pandang teori akuntansi positif telah banyak dilakukan dan memberikan hasil yang beragam. Setyorini \& Ishak (2012) menemukan bukti bahwa ketiga hipotesis menurut Watts dan Zimmerman yaitu bonus plan hypothesis, debt hypothesis, serta political cost hypothesis terbukti mempengaruhi CSR. Agustina, Sulia \& Rice (2017) menemukan bukti bahwa hipotesis bonus plan dan debt tidak berpengaruh terhadap CSR. Namun, hipotesis political cost tidak terbukti. Siregar \& Bachtiar (2010) juga menemukan bukti bahwa hipotesis debt tidak berpengaruh terhadap tanggung jawab sosial. Sedangkan, Belkaoui \& Karpik (1989) dalam penelitiannya menemukan bukti bahwa hipotesis debt dan political cost berpengaruh terhadap CSR. Penelitian ini bertujuan untuk menemukan bukti mengenai hubungan bonus plan hypothesis, debt hypothesis dan political cost hypothesis terhadap CSR perusahaan manufaktur di Indonesia.

Penelitian ini menggunakan obyek yaitu perusahaan manufaktur yang terdaftar di Bursa Efek Indonesia (BEI). Pemilihan perusahaan manufaktur sebagai obyek penelitian didasarkan pada asumsi bahwa perusahaan manufaktur bergerak di bidang yang berkaitan dengan sumber daya alam seperti memanfaatkan sumber daya alam (SDA) sebagai bahan utama produksi serta pembuangan limbah produksi yang berdampak pada alam, sehingga berpengaruh langsung terhadap kegiatan CSR. Penelitian ini akan melihat laporan keuangan perusahaan manufaktur yang berakhir pada tahun 2014, 2015 dan 2016. 
Manfaat yang ingin dicapai dalam penelitian ini yaitu untuk menambah wawasan bagi masyarakat bisnis dan profesi akuntan mengenai perilaku manajemen dalam mengelola laba dan pengaruhnya terhadap pelaksanaan CSR serta memperluas pemanfaatan dari teori akuntansi positif untuk menganalisis pengungkapan tanggung jawab sosial yang dilakukan oleh perusahaan.

\section{Telaah Pustaka}

\section{Corporate Social Responsibility (CSR)}

Dalam melakukan kegiatan bisnis, perusahaan bergantung pada lingkungan alam dan sosialnya, sehingga perusahaan memiliki tanggung jawab atas hal tersebut. Corporate Social Resposibility (CSR) adalah mekanisme bagi suatu organisasi untuk secara sukarela mengintegrasikan perhatian terhadap lingkungan dan sosial ke dalam operasinya dan interaksinya dengan stakeholders, yang melebihi tanggung jawab organisasi di bidang hukum (Anggraini, 2006). CSR lebih dari sekedar mematuhi peraturan lingkungan maupun sosial, namun juga menciptakan persepsi positif kepada pihak pemangku kepentingan (stakeholder) bahwa perusahaan telah bertanggung jawab atas pemanfaatan lingkungan dan sosialnya. Tanggung jawab sosial merupakan salah satu sarana komunikasi antara manajemen dengan stakeholder. Sebab salah satu tujuan CSR adalah menyampaikan informasi perusahaan kepada para pemangku kepentingan mengenai dampak terhadap lingkungan yang disebabkan oleh kegiatan perusahaan dan bagaimana kewajiban perusahaan atas penyelesaian dampak tersebut (Agustina \& Syadeli, 2012). Sedangkan menurut Hardiningsih \& Oktaviani (2012), tanggung jawab sosial adalah ketika perusahaan ikut terlibat dengan berbagai kegiatan sosial, kegiatan tersebut dapat memberikan nilai positif bagi perusahaan.

\section{Teori Akuntansi Positif}

PAT muncul sejak tahun 1960 dan menjadi lebih berkembang setelah dipelopori oleh Watts dan Zimmerman. PAT bertujuan untuk menjelaskan (to explain) fenomena yang sedang diamati dan memprediksi (to predict) fenomena yang belum diamati (Setijaningsih, 2012). Menjelaskan berarti menguraikan mengapa suatu praktik dilakukan, sedangkan prediksi artinya teori mampu memprediksi berbagai fenomena sosial yang diharapkan akan terjadi (Januarti, 2004). PAT dapat dijelaskan dalam dua perspektif yaitu perspektif oportunis dan perspektif efisiensi. Oportunis yaitu ketika terjadi peningkatan kekayaan manajemen namun tidak berdampak pada kekayaan secara agregat. Sedangkan perspektif efisiensi terjadi ketika manajemen bertindak untuk meningkatkan kekayaan seluruh pihak yang terlibat dalam kontrak (Setyorini \& Ishak, 2012). 
Sebuah organisasi terbentuk atas setiap kontrak yang mengikat oleh para pelaku yang bersikap oportunistik (Setyorini \& Ishak, 2012). Setiap kontrak akan menimbulkan biaya bagi perusahaan. PAT menjelaskan bagaimana akuntansi keuangan dapat digunakan untuk meminimalisasi biaya keagenan dari setiap pihak yang terlibat dalam kontrak yang masing-masing pihak mengutamakan kepentingannya (Utomo, 2013). Achmad, Subekti \& Atmini (2007) menyatakan bahwa PAT (contracting theory) merupakan penjelasan mengenai akuntansi sebagai alat pengawasan dalam pelaksanaan kontrak. Kontrak mencakup angka-angka akuntansi di dalamnya. Sedangkan akuntansi menyediakan informasi yang berguna bagi pengambilan keputusan perusahaan terhadap alokasi sumber daya, kompensasi manajemen dan perjanjian hutan (Achmad, Subekti, \& Atmini, 2007). Setiap tindakan yang dilakukan oleh individu ditujukan agar dapat memaksimalkan keuntungan pribadinya (Watts \& Zimmerman, 1978). Sehingga manajer akan berusaha untuk mempengaruhi angka akuntansi untuk memaksimalkan keuntungan pribadinya maupun perusahaan (Herawati, 2010). Watts \& Zimmerman (1990) merumuskan PAT dalam bentuk tiga hipotesis yaitu:

\section{Bonus Plan hypothesis}

Hipotesis ini menjelaskan bahwa jika dalam keadaan ceteris paribus, perusahaan yang menggunakan rencana bonus cenderung akan mempilih prosedur akuntansi yang memindahkan laba mendatang menjadi laba saat ini.

\section{Debt hypothesis}

Dalam ceteris paribus, perusahaan yang mempunyai rasio hutang yang tinggi lebih memungkinkan untuk memilih prosedur akuntansi yang memindahkan laba masa mendatang menjadi laba periode sekarang ini.

3. Political cost hypothesis

Dalam ceteris paribus, semakin besar biaya politik perusahaan maka akan semakin mungkin manajer untuk memilih prosedur akuntansi yang menangguhkan laba periode sekarang ke periode mendatang.

\section{Pengembangan Hipotesis}

\section{Pengaruh Rencana Bonus Terhadap CSR}

Apabila perusahaan memberikan insentif/bonus atas kinerja manajer, maka dalam melakukan pekerjaannya, manajer akan berusaha mencapai bonus tersebut (Setyorini \& Ishak, 2012). Rencana bonus manajemen dalam perusahaan biasanya didasarkan pada laba yang ditargetkan. Jika rencana bonus dikaitkan dengan laba yang diterima perusahaan maka manajer akan berusaha meningkatkan laba perusahaan supaya bonus yang diterima juga meningkat. Hal ini kemudian mendorong manajer cenderung untuk 
memindahkan laba masa mendatang menjadi laba periode saat ini (Watts \& Zimmerman, 1990). Indrawati (2009) menyatakan bahwa perusahaan yang memiliki tingkat tanggung jawab yang tinggi akan lebih menarik daya investor untuk berinvestasi. Sehingga nilai perusahaan, jika diproksikan melalui laba per lembar saham akan meningkat. Hal ini berdampak pada insentif yang diberikan kepada manajer. Dengan kata lain bonus (insentif) berpengaruh terhadap pelaksanaan tanggung jawab sosial.

Penelitian mengenai pengaruh bonus terhadap tanggung jawab sosial telah banyak dilakukan diantaranya yaitu Osifo \& Fasua (2017) yang memproksikan hipotesis rencana bonus dengan ROA (return on assets), dan menemukan bahwa ROA berpengaruh positif terhadap tanggung jawab sosial perusahaan. Sejalan dengan hal tersebut, (Setyorini \& Ishak, 2012) dalam penelitiannya menyatakan bahwa bonus plan hypothesis berpengaruh positif terhadap CSR.

$\mathrm{H}_{1}$ : Rencana bonus perusahaan berpengaruh positif terhadap tingkat pelaksanaan CSR

\section{Pengaruh Rasio Hutang Terhadap CSR}

Jika pendanaan perusahaan lebih besar dibiayai oleh hutang, maka tekanan perusahaan untuk taat kepada kreditur juga semakin besar. Dalam memberikan pinjaman, kreditur akan membuat perjanjian hutang dengan perusahaan. Kreditur akan membatasi pembayaran dividen, pembelian kembali saham, dan pengeluaran hutang tambahan untuk meyakinkan pembayaran kembali pokok dan bunga mereka, pembatasan ini biasanya diekpresikan dengan rasio-rasio keuangan seperti working capital levels, interest coverage dan net worth (Herawati, 2010).

Perusahaan dengan tingkat rasio hutang yang tinggi kemungkinan besar akan memilih metoda yang meningkatkan pendapatan (Watts \& Zimmerman, 1990). Semakin tinggi ketergantungan perusahaan terhadap kreditur, semakin tinggi pula keinginan untuk menghindari pelanggaran perjanjian hutang (debt covenant). Keputusan untuk melaksanakan tanggung jawab sosial mengakibatkan pengeluaran, sehingga menurunkan pendapatan (Belkaoui \& Karpik, 1989). Perusahaan akan menampilkan performa yang lebih baik agar kreditur dapat menginvestasikan dana secara lebih maksimal, sehingga perusahaan akan meminimalkan biaya, salah satunya biaya kegiatan sosial (Agustina, Sulia, \& Rice, 2017). Perusahaan dengan tingkat rasio hutang yang tinggi akan mengurangi tanggung jawab sosialnya untuk mengurangi pemeriksaaan kreditor (Siregar \& Bachtiar, 2010)

Belkaoui \& Karpik (1989) menemukan bukti bahwa rasio hutang (leverage) berpengaruh negatif terhadap kegiatan sosial. Penelitian lain dilakukan oleh Setyorini \& Ishak (2012) yang juga menemukan bukti bahwa terdapat 
hubungan negatif antara tanggung jawab sosial dengan leverage. Oleh karena itu penelitian ini merumuskan:

$\mathrm{H}_{2}$ : Rasio hutang perusahaan berpengaruh negatif terhadap tingkat pelaksanaan CSR

\section{Pengaruh Biaya Politik Terhadap CSR}

Bagi perusahaan-perusahaan besar dan menjadi sorotan publik, setiap angka yang dilaporkan dalam akuntansi memiliki konsekuensi ekonomi jika angka tersebut mempengaruhi pajak yang akan dibayar maupun subsidi yang akan diterima oleh perusahaan (Gumanti, 2002). Perusahaan akan berusaha untuk menurunkan laba yang mereka laporkan untuk mengurangi biaya politik, salah satunya yaitu dengan mengadakan tanggung jawab sosial (Watts \& Zimmerman, 1978). Dalam hipotesis biaya politik, perusahaan besar lebih berpotensi dalam melakukan transfer kekayaan kepada pihak politik (Agustina, Sulia, \& Rice, 2017). Perusahaan besar cenderung lebih menjadi sorotan publik dibandingkan dengan perusahaan kecil. Sehingga perusahaan besar akan lebih berpotensi terhadap pengeluaran biaya politik. Oleh karena itu, hipotesis biaya politik seringkali diproksikan dengan ukuran perusahaan. Perusahaan besar adalah perusahaan yang memiliki keuangan, manajerial dan teknikal yang mampu mengetahui bagaimana biaya sepanjang aktivitas CSR sesuai keuangan yang ada, ukuran perusahaan dapat diproksikan dari nilai kapitalisasi pasar, total aset, dan penjualan (Indrawati, 2009).

Penelitian untuk menguji pengaruh biaya politik terhadap tanggung jawab sosial dilakukan oleh Belkaoui \& Karpik (1989) yang menyatakan bahwa perusahaan besar cenderung akan lebih mengungkapkan informasi sosial mereka. Penelitian serupa dilakukan oleh Indrawati (2009) yang menemukan hasil bahwa semakin besar ukuran perusahaan maka kegiatan CSR yang dilakukan akan semakin luas. Setyorini \& Ishak (2012) dalam penelitiannya juga menemukan bukti bahwa political visibility yang diproksikan dengan ukuran perusahaan adalah perusahaan yang berpotensi terhadap biaya politik. Oleh karena itu perusahaan besar cenderung akan lebih melaksanakan tanggung jawab sosialnya untuk mengurangi biaya politik.

$\mathrm{H}_{3}$ : Biaya politik berpengaruh positif terhadap tingkat pelaksanaan CSR

\section{Metoda}

Populasi yang menjadi obyek dalam penelitian ini adalah seluruh perusahaan manufaktur yang terdaftar dalam Bursa Efek Indonesia (BEI) pada tahun 20142016. Jenis data yang digunakan dalam penelitian ini adalah data sekunder. Data yang menjadi obyek dalam penelitian ini adalah laporan tahunan yang diakses melalui website resmi BEI (www.idx.co.id). Metode penentuan sampel 
yang digunakan adalah metode purposive sampling. Kriteria dalam memilih sampel penelitian adalah:

1. Laporan tahunan memuat informasi mengenai tanggung jawab sosial perusahaan, dan indikator variabel yang akan diteliti yaitu return on asset (ROA), debt to equity ratio (DER), dan total aset.

2. Laporan tahunan menggunakan mata uang Rupiah.

Dari purposive sampling maka di dapat jumlah perusahan yang menjadi sampel dalam penelitian ini sebanyak 96 dengan kriteria pemilihan sampel sebagai berikut:

Tabel 1. Kriteria Pemilihan Sampel

\begin{tabular}{|c|c|c|}
\hline No & Kriteria Sampel & Jumlah \\
\hline & Perusahaan manufaktur yang terdaftar di BEI. & 141 \\
\hline 1. & $\begin{array}{l}\text { Perusahaan manufaktur yang tidak menerbitkan laporan tahunan } \\
\text { secara lengkap periode 2014-2016 }\end{array}$ & (4) \\
\hline 2. & $\begin{array}{l}\text { Laporan keuangan tidak menyediakan data yang dibutuhkan } \\
\text { mengenai tanggung jawab sosial perusahaan, total aset, total hutang, } \\
\text { total ekuitas, dan laba bersih perusahaan. }\end{array}$ & $(10)$ \\
\hline 3. & Laporan keuangan tidak disajikan dalam mata uang Rupiah & $(31)$ \\
\hline \multicolumn{2}{|r|}{ Jumlah Sampel } & 96 \\
\hline
\end{tabular}

\section{Definisi Operasional Variabel Dependen}

Variabel dependen dalam penelitian ini adalah pelaksanaan tanggung jawab sosial (CSR). Pelaksanaan CSR diukur berdasarkan CSR disclosure indeks (CSRI) dengan sistem checklist pokok laporan tahunan dengan standar menurut GRI G4 yang secara keseluruhan berjumlah 91 indikator kinerja. Indikator tersebut terdiri atas tiga kategori yaitu kategori ekonomi yang memiliki 9 indikator, kategori lingkungan dengan 34 indikator, dan kategori sosial yang terbagi ke dalam ketenagakerjaan (16 indikator), hak asasi manusia (12 indikator), masyarakat (11 indikator), serta tanggung jawab produk (9 indikator).

Mengacu dengan penelitian Indrawati (2009) penghitungan CSRI menggunakan pendekatan dikotomi yaitu dengan memberikan skor 1 jika instrumen diungkapkan, dan skor 0 jika instrumen tidak diungkapkan. Selanjutnya skor setiap pokok dijumlahkan untuk memperoleh total skor untuk setiap perusahaan. Rumus penghitungan CSRI dinyatakan sebagai berikut:

$\operatorname{CSRI}_{\mathrm{i}}=\frac{\sum X_{i i}}{n_{i}}$

Keterangan:

$\mathrm{CSRI}_{\mathrm{i}} \quad$ : Corporate Social Responsibility Disclosure index perusahaan

$\mathrm{N}_{\mathrm{i}} \quad$ : jumlah pokok untuk perusahaan 
$\mathrm{X}_{\mathrm{ii}} \quad$ : dummy variabel: $1=$ jika pokok i diungkapkan, $0=$ jika pokok i tidak diungkapkan.

\section{Definisi Operasional Variabel Independen}

Terdapat 3 variabel independen dalam penelitian ini yaitu bonus plan, debt/equity, dan political cost.

1. Bonus Plan (X1)

Setiap perubahan dalam kebijakan akuntansi yang dapat menyebabkan peningkatan laba perusahaan akan berpengaruh terhadap besarnya insentif (bonus) yang diterima (Watts \& Zimmerman, 1978). Semakin besar pendapatan yang dilaporkan maka semakin besar pula bonus yang diterima perusahaan. Sehingga dalam penelitian ini, bonus akan dikaitkan dengan profitabilitas perusahaan yang diukur dengan Return on Asset (ROA).

Mengacu pada penelitian yang dilakukan oleh Agustina, Sulia \& Rice (2017), hipotesis bonus diukur dengan parameter sebagai berikut:

$\mathrm{ROA}=\frac{\text { Net Income }}{\text { Total Assets }} \times 100 \%$

2. $\operatorname{Debt}(\mathrm{X} 2)$

Sejalan dengan penelitian Belkaoui \& Karpik (1989), untuk mengukur seberapa besar perusahaan bergantung pada kreditur dalam membiayai aktiva perusahaan, maka pengukuran debt hypothesis menggunakan debt to equity ratio (DER). Semakin tinggi nilai rasio ini maka semakin besar resiko yang akan dihadapi, sehingga akan semakin besar pula tingkat pengembalian yang diinginkan investor.

$\mathrm{DER}=\frac{\text { total } \text { debt }}{\text { total } \text { equity }}$

\section{Political cost (X3)}

Besarnya biaya politik sangat bergantung pada ukuran perusahaan (Watts \& Zimmerman, 1978). Dalam penelitian ini, ukuran (size) perusahaan yang mempengaruhi biaya politik akan diukur menggunakan total aset (Indrawati, 2009).

\section{Teknik dan Langkah Analisis Data}

Teknik analisis data dalam penelitian ini yaitu analisis regresi berganda menggunakan program SPSS. Langkah analisis data yang dilakukan adalah sebagai berikut: Sebelum menganalisis data, dilakukan beberapa uji asumsi klasik untuk mengetahui bahwa metode analisis regresi menunjukkan hubungan yang signifikan dan representatif. Pengujian yang dilakukan diantaranya adalah uji normalitas data, multikolinearitas, heterososkedastisitas, serta uji autokorelasi. 
Uji normalitas data adalah pengujian yang bertujuan untuk mengetahui apakah dalam model regresi, variabel pengganggu atau residual memiliki distribusi normal atau tidak (Gozali, 2005). Pengujian dapat dilakukan dengan uji grafik P-Plots. Apabila titik-titik penyebaran data menyebar dan mengikuti garis diagonal dalam grafik p-plots maka data telah terdistribusi secara normal.

Uji multikolinearitas digunakan untuk mengetahui adanya hubungan linier diantara variabel bebas (Gozali, 2005). Untuk mendeteksi adanya gejala multikolinearitas dapat dilihat dari nilai variance inflation factor (VIF) dan tolerance (TOL). Jika nilai VIF lebih dari 10 maka terjadi multikolinearitas, dan jika TOL kurang dari 10\% maka tidak terjadi multikolinearitas.

Heterokedastisitas adalah kondisi ketika variabel terikat tidak konstan (Nachrowi, 2006 dalam Risa, 2012). Kondisi ini menyebabkan variabel bebas memiliki nilai variabel terikat yang berbeda-beda. Model regresi yang baik adalah model regresi yang bersifat homokedastisitas. Pengujian dalam penelitian ini menggunakan uji Park, apabila nilai signifikansi lebih dari 0.05 maka data dinyatakan terhindar dari gejala heterokedastisitas. Sebaliknya, jika nilai signifikansi kurang dari 0,05 maka terjadi heterokedastisitas.

Autokorelasi adalah terjadinya korelasi antara satu variabel eror dengan variabel eror yang lain (Handoko, 2013). Uji autokorelasi dapat dilakukan dengan melakukan pengujian terhadap nilai uji Durbin-Watson (uji DW). Apabila nilai Durbin Watson berada di atas batas atas (dU) dan tidak lebih dari 4-dU maka tidak terjadi gejala autokorelasi $(\mathrm{dU}<\mathrm{D}<4-\mathrm{dU})$.

Selanjutnya dilakukan analisis data menggunakan metode regresi berganda dengan persamaan:

$\mathrm{CSR}=\alpha+\beta 1 \mathrm{BP}+\beta 2 \mathrm{DE}+\beta 3 \mathrm{PC}+$

Keterangan:

CSR = tanggung jawab sosial

$\alpha \quad=$ konstanta

$\beta 1 \mathrm{BP}=$ bonus plan

$\beta 2 \mathrm{DE}=$ debt to equity

$\beta 3 \mathrm{PC}=$ political cost

$\boldsymbol{\varepsilon}=$ error term 


\section{Hasil dan Pembahasan}

\section{Hasil}

\section{Statistik Deskriptif}

Tabel 1 menunjukkan hasil uji statistik deskriptif dengan nilai rata-rata CSR sebesar 0,069, atau rata-rata perusahaan mengungkapkan 6 dari 91 indikator pengungkapan CSR berdasarkan GRI. Sehingga dapat dikatakan bahwa nilai CSR perusahaan manufaktur yang terdaftar di BEI pada tahun 2014-2016 masih rendah.

Tabel 1. Statistik Desktiptif

\begin{tabular}{llllll}
\hline & N & Minimum & Maximum & Mean & Std. Deviation \\
\hline CSR & 288 & 0,022 & 0,330 & 0,069 & 0,037 \\
BP & 288 & $-0,731$ & 1,674 & 0,058 & 0,140 \\
DE & 288 & $-31,037$ & 13,977 & 0,957 & 2,566 \\
SZ & 288 & 25,246 & 33,199 & 28,338 & 1,548 \\
Valid N & 288 & & & & \\
\hline
\end{tabular}

Sumber: data sekunder yang diolah (2018)

Pada variabel rencana bonus nilai ini menunjukkan besarnya rencana bonus yang akan diterima manajer jika dihitung berdasarkan ROA perusahaan. ROA yang mendekati 1 adalah ROA yang baik. Karena berarti setiap aset yang dimiliki perusahaan dapat dipergunakan untuk menghasilkan laba. Nilai ratarata variabel rencana bonus yaitu 0,058. Nilai ROA tertinggi sebesar 1,674 adalah PT Ultrajaya Milk Industry Tbk pada tahun 2016. Sedangkan nilai ROA terendah yaitu -0,731 adalah Merck Sharp Dohme Pharma Tbk pada 2014.

Variabel rasio hutang mempunyai rata-rata 0,9572 . Nilai rasio debt to equity dibawah 1 sehingga rata-rata perusahaan yang menjadi obyek penelitian memiliki hutang yang tidak lebih besar dibandingkan ekuitas perusahaan. Nilai tertinggi sebesar 13,98, sedangkan untuk nilai terendah yaitu -31,04 kedua nilai tersebut adalah adalah Merck Sharp Dohme Pharma Tbk tahun 2015 dan tahun 2014. Pada tabel juga dapat dilihat nilai rata-rata ukuran perusahaan sebesar 28,3380. Nilai tertinggi adalah 33,20 atau Rp 261.855.000.000.000 yang berasal dari Astra International Tbk pada tahun 2016. Sedangkan nilai terendah yaitu 25,25 atau Rp 92.041.274.561 berasal dari PT. Primarindo Asia Infrastructure Tbk pada tahun 2016.

\section{Uji Asumsi Klasik}

Dalam penelitian ini sudah memenuhi uji asumsi klasik yang terdiri atas uji normalitas, uji Multikolinearitas, Uji Heteroskedastisitas dan Uji Autokorelasi sebagai berikut: 


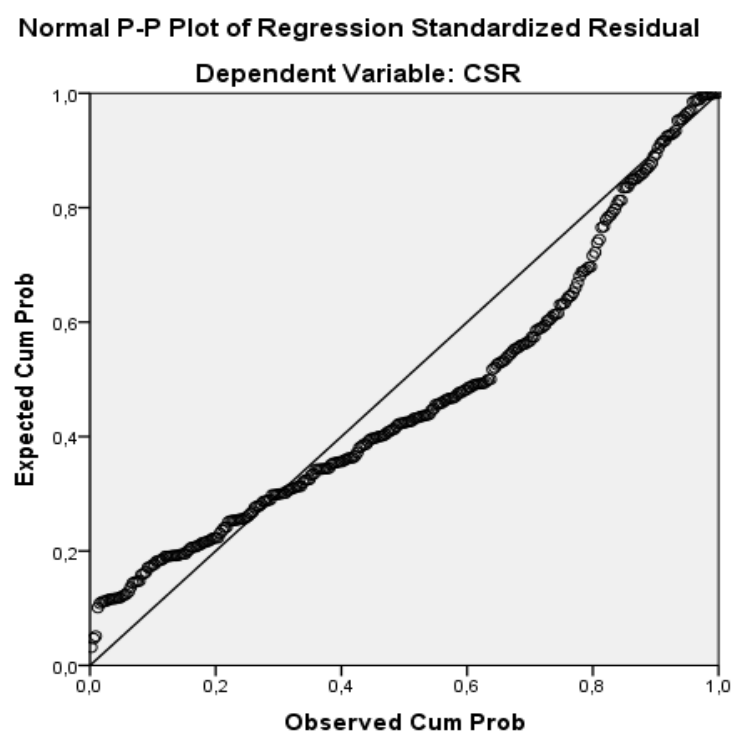

Gambar 1. Hasil Uji Normalitas

Sumber: data yang telah diolah menggunakan SPSS 22

Gambar di atas menyimpulkan bahwa data dalam penelitian ini terdistribusi secara normal. Karena data menyebar disekitar dan mengikuti garis diagonal.

Tabel 2. Hasil Uji Multikolinearitas, Uji Heteroskedastisitas dan Uji Autokorelasi

\begin{tabular}{|c|c|c|c|c|c|c|}
\hline \multicolumn{7}{|c|}{ Panel A. Uji Multikolinearitas } \\
\hline Variabel & \multicolumn{3}{|c|}{ Tolerance } & \multicolumn{3}{|c|}{ Kesimpulan } \\
\hline $\mathrm{BP}$ & \multicolumn{2}{|c|}{0,927} & & 1,078 & \multicolumn{2}{|c|}{ Tidak Ada Multikolinearitas } \\
\hline $\mathrm{DE}$ & \multicolumn{2}{|c|}{0,943} & & 1,061 & \multicolumn{2}{|c|}{ Tidak Ada Multikolinearitas } \\
\hline SZ & \multicolumn{2}{|c|}{0,982} & & 1,018 & \multicolumn{2}{|c|}{ Tidak Ada Multikolinearitas } \\
\hline \multicolumn{7}{|c|}{ Panel B. Uji Heteroskedastisitas } \\
\hline Model & \multicolumn{4}{|c|}{ Sig. } & \multicolumn{2}{|c|}{ Kesimpulan } \\
\hline $\mathrm{BP}$ & \multicolumn{4}{|c|}{0,198} & \multicolumn{2}{|c|}{ Tidak Ada Heterokadastisitas } \\
\hline $\mathrm{DE}$ & \multicolumn{4}{|c|}{0,687} & \multicolumn{2}{|c|}{ Tidak Ada Heterokadastisitas } \\
\hline $\mathrm{SZ}$ & \multicolumn{4}{|c|}{0,619} & \multicolumn{2}{|c|}{ Tidak Ada Heterokadastisitas } \\
\hline \multicolumn{7}{|c|}{ Panel C. Uji Autokorelasi } \\
\hline $\mathrm{K}$ & $\mathrm{N}$ & $\mathrm{d}_{\mathrm{L}}$ & $\mathrm{d}_{\mathrm{U}}$ & 4-dU & $4-d L$ & Kesimpulan \\
\hline 3 & 288 & 1,7396 & 1,8213 & 2,1787 & $2,2604 \quad 1,900$ & $\begin{array}{c}\text { Tidak Ada } \\
\text { Autokorelasi }\end{array}$ \\
\hline
\end{tabular}

Sumber: data yang telah diolah menggunakan SPSS 22

Tabel 3 menunjukkan bahwa semua variabel memiliki nilai Tolerance lebih dari 0,10 dan Variance Inflation Factor (VIF) kurang dari 10, sehingga dapat disimpulkan bahwa tidak terdapat gejala multikolinearitas antar semua 
variabel bebas yang terdapat dalam penelitian. Berdasarkan tabel hasil uji heterokedastisitas di atas, diperoleh nilai signifikansi variabel rencana bonus (BP) sebesar 0,198. Variabel debt (DE) mempunyai nilai signifikansi sebesar 0,687 serta variabel political cost (PC) dengan nilai signifikansi sebesar 0,619. Nilai signifikansi dari ketiga variabel lebih besar dari 0,05 sehingga ketiga variabel dinyatakan terhindar dari gejala heterokedastisitas. Menurut ketentuan Durbin Watson, data dikatakan terhindar dari autokorelasi jika nilai Durbin Watson (DW) berada diantara dU (batas atas) sampai dengan 4-dU. Dengan jumlah sampel 288 dan 3 variabel independen maka diperoleh nilai dari tabel $\mathrm{dU}=1,8213$ dan 4-dU=2,1787. Nilai DW hasil perhitungan seperti ditunjukkan pada tabel diatas yaitu 1,900. Dengan demikian penelitian ini terbebas dari autokorelasi, karena 1,8213 $<1,900<2,1787$.

Hasil uji F dan uji koefisien determinasi dapat dilihat dalam Tabel 4:

Tabel 4. Hasil Uji F dan Uji Koefisien Determinasi

\begin{tabular}{|c|c|c|c|c|c|c|}
\hline \multicolumn{7}{|c|}{ Panel A. Hasil Uji F } \\
\hline & Model & Sum of Squares & Df & Mean Square & $\mathrm{F}$ & Sig. \\
\hline \multirow[t]{3}{*}{1} & Regression & 0,026 & 3 & 0,009 & 6,961 & 0,000 \\
\hline & Residual & 0,358 & 284 & 0,001 & & \\
\hline & Total & 0,384 & 287 & & & \\
\hline \multicolumn{7}{|c|}{ Panel B. Hasil Koefisien Determinasi } \\
\hline Model & $\mathrm{R}$ & R Square & $\begin{array}{l}\text { Adjusted R } \\
\text { Square }\end{array}$ & \multicolumn{2}{|c|}{$\begin{array}{l}\text { Std. Error of } \\
\text { the Estimate }\end{array}$} & $\begin{array}{l}\text { Durbin- } \\
\text { Watson }\end{array}$ \\
\hline 1 & 0,262 & 0,068 & 0,059 & \multicolumn{2}{|c|}{0,035} & 1,900 \\
\hline
\end{tabular}

Sumber: data yang telah diolah menggunakan SPSS 22

Uji F dilakukan untuk menguji apakah secara bersama-sama variabel bebas mampu menjelaskan variabel terikat secara baik. Dengan kata lain, Uji-F dilakukan untuk mengetahui apakah model yang digunakan dalam penelitian telah fix atau tidak. Dari hasil pengolahan data pada tabel diatas diperoleh nilai F hitung sebesar 6,961 dengan nilai signifikansi 0,000. Nilai signifikansi 0,000 $<0,05$ maka variabel bebas secara bersama-sama berpengaruh signifikan terhadap variabel terikat.

Dari tabel diatas menunjukkan nilai Adjusted R Square sebesar 0,059. Hal ini berarti pelaksanaan CSR perusahaan manufaktur yang terdaftar di BEI periode 2014-2016 dapat dijelaskan oleh variabel bebas yaitu rencana bonus, ketergantungan terhadap hutang, dan ukuran perusahaan sebesar 5,9\% dan sisanya $94,1 \%$ ditentukan oleh variabel lain yang tidak dianalisis dalam penelitian ini. 
Tabel 5. Hasil Analisis Regresi Linier Berganda

\begin{tabular}{ccccc}
\hline Variabel & $\mathrm{B}$ & $\mathrm{t}$ & Sig. & Hipotesis \\
\hline (constant) & $-0,071$ & $-1,835$ & 0,067 & \\
BP & 0,037 & 2,373 & 0,018 & Diterima \\
DE & 0,000 & $-0,432$ & 0,666 & Ditolak \\
SZ & 0,005 & 3,558 & 0,000 & Diterima \\
\hline
\end{tabular}

Sumber: data yang telah diolah menggunakan SPSS 22

\section{Pembahasan}

\section{Pengaruh Rencana Bonus terhadap CSR}

Hipotesis pertama dalam penelitian ini yaitu rencana bonus berpengaruh positif terhadap pelaksanaan CSR. Berdasarkan pengujian hipotesis, maka hipotesis pertama diterima. Keputusan untuk mengungkapkan kegiatan sosial perusahaan dapat meningkatkan perhatian masyarakat dan investor sehingga dapat membangun citra yang baik dan pada akhirnya meningkatkan kinerja ekonomi perusahaan. Hal ini dapat meningkatkan profitabilitas, sehingga bonus yang diperoleh manajer akan meningkat.

Hasil penelitian diatas mendukung Osifo \& Fasua (2017) yang menyatakan bahwa perusahaan yang terlibat dengan kegiatan sosial memiliki tingkat pengembalian investasi yang lebih baik daripada perusahaan yang tidak terlibat. Jika manajer diberi insentif atas kinerja mereka berdasar harga saham maupun profitabilitas perusahaan, maka manajer akan berusaha untuk meningkatkannya supaya bonus yang manajer peroleh juga meningkat. Pelaksanaan CSR dapat meningkatkan kinerja perusahaan, sehingga manajer akan diberi insentif (Setyorini \& Ishak, 2012). Namun tidak mendukung hasil penelitian Agustina, Sulia \& Rice (2017) yang menyatakan bahwa bonus plan hypothesis tidak berpengaruh terhadap tanggung jawab sosial perusahaan. Perusahaan cenderung memberikan perhatian terhadap kegiatan sosialnya, sehingga kegiatan sosial akan selalu stabil dilakukan perusahaan. Maka besar kecilnya kompensasi bonus yang diterima manajer tidak berpengaruh terhadap pelaksanaan CSR.

\section{Pengaruh Rasio Hutang terhadap CSR}

Hipotesis kedua dalam penelitian ini yaitu rasio hutang perusahaan berpengaruh negaif terhadap pelaksanaan CSR. menunjukkan bahwa debt tidak berpengaruh terhadap pelaksanaan CSR. Dengan demikian hipotesis kedua ditolak. Perusahaan telah menjalin hubungan yang baik dengan pihak kreditur, sehingga kreditur sudah memiliki kepercayaan kepada perusahaan dan tidak lagi mengawasi rasio keuangan perusahaan. Hal ini menyebabkan rasio 
leverage tidak berpengaruh terhadap kegiatan sosial perusahaan (Wijaya, 2016).

Penemuan ini selaras dengan hasil penelitian Wijaya (2016), Sembiring (2003) dan Badjuri (2011) bahwa tinggi rendahnya rasio hutang tidak berpengaruh terhadap tanggung jawab sosial perusahaan. Namun berbeda dengan hasil penelitian diatas, Belkaoui \& Karpik (1989) yang menemukan bukti bahwa leverage berpengaruh negatif tanggung jawab sosial perusahaan.

\section{Pengaruh Biaya Politik terhadap CSR}

Hipotesis ketiga dalam penelitian ini menyatakan bahwa biaya politik berpengaruh positif terhadap pelaksanaan CSR diterima. Perusahaan yang besar cenderung menjadi sorotan publik dan berpotensi terhadap adanya biaya politik. Keputusan mengungkapkan tanggung jawab sosial dapat menurunkan laba. Sehingga dapat mencegah terjadinya transfer biaya politik. Maka perusahaan akan lebih melaksanakan kegiatan sosialnya.

Hasil penelitian ini didukung oleh Indrawati (2009) dan Belkaoui \& Karpik (1989) yang menyatakan bahwa semakin besar ukuran perusahaan maka semakin luas tanggung jawab sosial yang dilakukan perusahaan. Setyorini \& Ishak (2012) menyatakan bahwa perusahan besar yang menjadi sorotan publik dan berpotensi terhadap biaya politik akan lebih banyak melakukan CSR. Badjuri (2011) mengungkapkan bahwa ukuran perusahaan yang berpengaruh positif terhadap CSR didukung adanya teori legitimasi bahwa perusahaan besar akan melaksanakan tanggung jawab sosialnya untuk memperoleh legitimasi dari stakeholder.

\section{Simpulan}

Penelitian ini dilakukan untuk mengetahui bagaiman pengaruh rencana bonus, rasio hutang, dan biaya politik terhadap pelaksanaan tanggung jawab sosial perusahaan manufaktur yang terdaftar di Bursa Efek Indonesia (BEI) pada tahun 2014-2016. Berdasarkan hasil temuan penelitian dan pengujian hipotesis yang telah dilakukan, maka dapat disimpulkan bahwa: Rencana bonus berpengaruh positif signifikan terhadap pelaksanaan CSR. Hal ini berarti apabila rencana bonus yang diterima manajer perusahaan meningkat maka pelaksanaan CSR yang dilakukan juga akan meningkat. Rasio hutang tidak berpegaruh terhadap pelaksanaan CSR. Hal ini menandakan bahwa jika perusahaan memiliki rasio hutang yang tinggi, maka pelaksanaan CSR yang dilakukan perusahaan akan tetap atau konstan. Biaya politik berpengaruh positif signifikan terhadap pelaksanaan CSR. Artinya, semakin besar biaya politik yang harus dikeluarkan perusahaan, maka semakin luas pelaksanaan CSR yang dilakukan perusahaan. 
Meskipun penelitian telah dirancang dan dikembangkan sedemikian rupa, namun masih terdapat beberapa keterbatasan yang masih perlu untuk diperbaiki oleh penelitian selanjutnya, antara lain: Dalam penelitian ini, rencana bonus diukur dengan menggunakan ROA, pengukuran ini dianggap kurang tepat karena profitabilitas perusahan kurang mencerminkan bonus yang diperoleh manajer. Dalam penelitian ini, biaya politik diukur menggunakan ukuran perusahaan, hasil menunjukkan bahwa ukuran perusahaan tidak menentukan besar kecilnya biaya yang dikeluarkan perusahaan berkaitan dengan biaya politik. Dari segi tehnik analisis dalam penelitian ini masih menggunakan regresi berganda, disarankan untuk penelitian mendatang menggunakan data panel untuk hasil yang lebih baik. Untuk penelitian mendatang disarankan untuk menggunakan pengukuran yang lebih tepat untuk variabel rencana bonus dan ukuran perusahaan, misalnya dengan menggunakan ESOP dan biaya yang berkaitan dengan kegiatan politik perusahaan.

\section{Daftar Pustaka}

Achmad, K., Subekti, I., \& Atmini, S. (2007). Investigasi Motivasi dan Strategi Manajemen Laba pada Perusahaan Publik d Indonesia. Jurnal TEMA, 37-55.

Agustina, N. E., \& Syadeli, M. (2012). Corporate Governance dan Profitabilitas: Pengaruhnya terhadap Corporate Social Responsibility Perusahaan yan Listing di BEI. Conference in Business, Accounting and Management (CBAM), 697-710.

Agustina, Sulia, \& Rice. (2017). Pengungkapan Tanggung Jawab Sosial dan Nilai Perusahaan: Dari Sudut Pandang Teori Akuntansi Positif dan Corporate Governance. Jurnal Dinamika Akuntansi dan Bisnis, 4(1), 33-44.

Anggraini, F. R. (2006). Pengungkapan Informasi Sosial dan Faktor-Faktor yang MempengaruhiPengungkapan Informasi Sosial dalam Laporan Keuangan Tahunan (StudiEmpiris pada Perusahaan-Perusahaan yang terdaftar Bursa Efek Jakarta). Simposium Nasional Akuntansi, 9.

Badjuri, A. (2011, Mei). Faktor-faktor Fundamental, Mekanisme Corporate Governance, Pengungkapan Corporate Social Responsibility (CSR) Perusahaan. Dinamika Keuangan dan Perbankan, 38-54.

Belkaoui, A., \& Karpik, P. G. (1989). Determinants of The Corporate Decision to Disclose Social Information. Accounting, Auditing and Accountability Journal, 2(1), 3651.

Gozali, I. (2005). Aplikasi Analisis Multivariate dengan Program SPSS. Semarang: Badan Penerbit UNDIP.

Gumanti, T. A. (2002). Pilihan-pilihan Akuntansi dalam Aplikasi Teori Akuntansi Positif. Jurnal Akuntansi dan Auditing Indonesia, 6(1), 83-101.

Handoko, A. (2013). Analisis Regresi Berganda.

Hardiningsih, P., \& Oktaviani, R. M. (2012). Efektivitas Corporate Governance, Corporate Social Responsibility, dan Earning Management Terhadapa Nilai Perusahaan. Conference in Business, Accounting and Management, 8. 
Herawati, N. (2010). Manajemen Laba pada Perusahaan yang Melanggar Perjanjian Utang. Jurnal Ekuitas, 14(1), 97-113.

Indrawati, N. (2009). Pengungkapan Corporate Social Responsibility (CSR) dalam Annual Report serta Pengaruh Political Visibility dan Economic Performance. Jurnal Pendidikan Ekonomi dan Bisnis, 1(1), 1-11.

Januarti, I. (2004). Pendekatan dan Kritik Teori Akuntansi Positif. Jurnal Akuntansi dan Auditing, 1, 83-94.

Januarti, I. (2004). Pendekatan dan Kritik Teori Akuntansi Positif. Jurnal Akuntansi dan Auditing, 1, 83-94.

Khodir, A. (2012). Menyingkap Selubung Ideologi Corporate Social Responsibility (CSR) di Indonesia: Analisa Teori Kritis Terhadap Keberpihakan CSR di Indonesia (Doktoral Disertasi).

Malhotra, D. (2013). CSR As A Strategy. The International Journal Of Business \& Management, 21-25.

Osifo, I. U., \& Fasua, H. K. (2017). Social and Environmental Disclosures and Holistic Growth in the Positive Accounting Theory (PAT) View. IOSR Journal of Business and Management (IOSR-JBM), 9(6), 1-8.

Sembiring, E. R. (2003). Kinerja Keuangan, Political Visibility, Ketergantungan pada hutang, dan pengungkapan Tanggung Jawab Sosial Perusahaan. Simposium Nasional Akuntansi, 249-259.

Setijaningsih, H. T. (2012, September). Teori Akuntansi Positif dan Konsekuensi Ekonomi. Jurnal Akuntansi, XVI(3), 427-438.

Setyorini, C. T., \& Ishak, Z. (2012). Corporate Social and Environmental Disclosure: A Positive Accounting Theory View Point. International Journal of Business and Social Science, 3(9), 152-164.

Siregar, S. V., \& Bachtiar, Y. (2010). Corporate Social Reporting: Empirical Evidence from Indonesia Stock Exchange. International Journal of Islamic and Middle Eastern Finance and Management, 3(3), 241-252.

Utomo, R. B. (2013). Pengaruh Kekuatan Bonus Terhadap Metode Persediaan. Jurnal Ilmiah Akuntansi dan Humanika, 3(1), 912-920.

Watts, R. L., \& Zimmerman, J. L. (1978). Towards a Positive Theory of The Determination of Accounting Standards. The Accounting Review, LIII(1), 112134.

Watts, R. L., \& Zimmerman, J. L. (1990, January). Positive Accounting Theory: A Ten Year Perspective. 131-156. 
Wijaya, M. (2016). Faktor-Faktor Yang Mempengaruhi Pengungkapan Tanggung Jawab Sosial Pada Perusahaan Manufaktur yang Terdaftar di Bursa Efek Indonesia. Jurnal Ilmiah Mahasiswa Akuntansi, 1(1), 26-30. 